Journal of Applied Pharmaceutical Science Vol. 2 (10), pp. 031-034, October, 2012

Available online at http://www.japsonline.com

DOI: 10.7324/JAPS.2012.21006

ISSN 2231-3354 (cc) BY-NC-SA

\title{
Arginase activity and nitric oxide levels may beconsidered as tumor markers in breast cancer
}

\author{
Iclal GEYIKLI ${ }^{1}$, Nurdan OZLU CEYLAN ${ }^{1}$, Celalettin CAMCI $^{2}$ \\ ${ }^{1}$ Assoc Prof, Department of Biochemistry, Faculty of Medicine, University of Gaziantep. \\ ${ }^{2}$ Department of Medical Oncology, Faculty of Medicine, University of Gaziantep, Oncology Hospital, Gaziantep, 27310, TURKEY.
}

\section{ARTICLE INFO}

\section{Article history:}

Received on: 06/08/2012

Revised on: 29/08/2012

Accepted on: 07/09/2012

Available online: $28 / 10 / 2012$

Key words:

Arginase,

cancer,

nitricoxide

\begin{abstract}
To investigate the relationship of breast cancer with serum arginase activity and nitric oxide levels. Arginase (L-arginine ureohidrolase, EC. 3.5.3.1) is the last enzyme of urea cycle which converts arginine into urea and ornithine. nitric oxide, a product of L-arginine and nitric oxide synthetase reaction, is a hormone, a reactive oxygen species, neurotransmitter, mediator, cytoprotective molecule, and the only endogenous molecule that acts as a cytotoxic molecule. This study was done at Gaziantep University Research Hospital with 30 breast cancer patients (30-77) and with 34 healthy people (30-75) to diagnose breast cancer. The majority $(\mathrm{n}=28)$ was ductal while the rest were medullary and papillary cancers. Serum arginase activity was measured by thiosemicarbazide diasetilmonoksim urea method in U/L that was modified. Also, serum nitric oxide levels were measured by the Griess method in terms of $\mathrm{mmol} / \mathrm{L}$. Serum arginase activity was determined as $17.8 \pm 2.5$ $(\mathrm{X} \pm \mathrm{SE}) \mathrm{U} / \mathrm{L}$ in the patient group and $6.8 \pm 0.9 \mathrm{U} / \mathrm{L}$ in the control group; the cancer patients showed a significant increase $(\mathrm{t}=3,649, \mathrm{p}<0.01)$. Serum nitric oxide levels were found $139.4 \pm 7.4 \mathrm{mmol} / \mathrm{L}$ in the breast cancer group, and $95.9 \pm 7.6 .1 \mathrm{mmol} / \mathrm{L}$ in the healthy group. nitric oxide levels were found to be significant in the analysis $(t=4,197, \mathrm{p}<0.001)$. In this study, a significant increase in serum arginase and nitric oxide activity was observed for the breast cancer patients, and it was concluded that both could be important for the diagnosis of breast cancer and for its treatment.
\end{abstract}

\section{INTRODUCTION}

Nitric oxide (NO) is one of the simplest biologically active molecules in biochemistry that is synthesized from $\mathrm{L}$ arginine amino acid by the enzyme nitric oxide synthase (NOS). It is the only endogenous molecule that acts as a mediator, a hormone, a reactive oxygen species (ROS), neurotransmitter, cytoprotective and cytotoxic molecule (Akyol et al., 2004). A decrease in NO production stimulates oxidative phosphorylation and increases peripheral oxygen uptake (Szabo C et al., 1995). It is caused by lipid peroxidation, nitrosylation of molecules, inactivation of sodium channels, and redox reaction with metals such as iron and copper (Mayer and Hemmens, 1997).

\footnotetext{
* Corresponding Author
}

Mailbox: 39, Branch Campus 27310, Gaziantep / Turkey

Phone: 903423606060 / 77785, Fax: 903423601617
The enzyme arginase (EC.3.5.3.1) hydrolyses L-arginine amino acid to urea and ornithine using two isoenzymes (Levillain et al., 2005; Vockley et al., 1996). While ariginase I among isoenzymes mostly found in liver and functions in the synthesis of urea, arginase II plays a mitochondrial enzyme in the extra-hepatic tissues (Srivastava and Ratha, 2010; Wu and Morris, 1998). Arginase II isozyme which synthesizes glutamic acid, proline and ornithine metabolite which the substrate in the synthesizes of polyamines (Russell and McVicker, 1972; Tabor and Tabor, 1984). The relationship between the NOS and arginase involves not only the use of the same substrate (Hecker et al., 1995; Meyer et al., 1997). In healthy individuals, sufficient arginase activity can limit the use of arginine for the synthesis of NO [Currie et al., 1979; Vodovotz et al., 1994). In many studies, macrophage- 
induced arginase activity in wounds has shown to be involved in tissue healing and protecting against inflammation and infection. In addition, the enzyme arginase removes arginine from the media by using it and thereby affects the level of NO (Meyer et al., 1997; Shearer et al., 1997).

\section{MATERIAL AND METHODS}

Participants: The present study included 31 patients aged from 30 to $77(48.03 \pm 2.51)$ years and diagnosed with breast cancer in Gaziantep University Oncology Hospital and 34 healthy volunteers aged from 30 to $75(48.66 \pm 2.55)$ years. The difference between the mean ages was not significant ( $p>0.05)$. The majority of breast cancers were ductal carcinoma $(\mathrm{n}=28)$ and the remainder were medullary and papillary carcinomas. Sera obtained from blood samples taken on while fasting in the morning were stored at $-80^{\circ} \mathrm{C}$ until the day of operation. The study was conducted after obtaining approval from local ethics committee of Gaziantep University on 30.06.2008.

Test methods: Arginase activity in the serum was studied spectrophotometrically with a modified method of Thiosemicarbazide Diacetyl Monoxime Urea (TDMU) (Ahi et al.,1999; Geyer and Dabich, 1971). NO levels were also measured spectrophotometrically by the Griess method. With this method, nitrous and nitrate levels measured and NO level calculated indirectly (Cortas and Wakid, 1990).

Statistical methods: The data were evaluated using SPSS software. Student "t" test and Mann-Whitney test were used for dependent and independent groups, respectively. In addition, Pearson correlation analysis was performed (Habbema et al., 2002; Lang and Secic, 1997).

\section{RESULT AND DISCUSSION}

There was no significant difference between the mean ages of 31 breast cancer patients aged from 30 to $77(48.03 \pm 2.51)$ years and 34 healthy volunteers aged from 30 to $75(48.66 \pm 2.55)$ years $(p>0.05)$. The mean arginase activity [arithmetic mean + standard error $(\mathrm{x} \pm \mathrm{SE})]$ in the healthy group was $6.88 \pm 0.9(0.4$ 26) $\mathrm{U} / \mathrm{L}$, whereas this ratio was $17.88 \pm 2: 57 \mathrm{U} / \mathrm{L}$ in the breast cancer group. The comparison of the arginase activity between breast cancer patients and healthy control group showed three-fold increase in arginase activity in cancer group and this increase was statistically significant $(\mathrm{t}=649, \mathrm{p}<0.001)$.

NO levels were $95.9 \pm 6.1 \mathrm{mmol} / \mathrm{L}$ in healthy individuals and $139 \pm 7.4 \mathrm{mmol} / \mathrm{L}$ in the breast cancer group. NO levels were also higher in the breast cancer group and the difference was statistically significant $(t=4197, \mathrm{P}<0.001)$. The results were within $95 \%$ confidence intervals (CI:95\%). The results are shown in Table 1 and 2. In addition, the values are shown graphically in Chart 1. Arginase activity was done with Pearson correlation analysis found a weak correlation between the level of NO $(r=$ $0.895, \mathrm{p}<0.02)$.
Table. 1: Arginase activity and NO levels in breast cancer and control groups.

\begin{tabular}{llll} 
Parameters & $\begin{array}{l}\text { Min - Max } \\
\text { Cancer Group } \\
\text { studied }\end{array}$ & $\begin{array}{l}\text { Min - Max } \\
\text { Healthy Group } \\
(\mathbf{n}=\mathbf{3 0})\end{array}$ & $\begin{array}{l}\mathbf{P}=\mathbf{3 4}) \\
(\mathbf{X}+\mathbf{S E})\end{array}$ \\
\hline Arginase & $17.88 \pm 2.57$ & $6.88 \pm 0.9$ & $\mathrm{t}=3,64$ \\
Activity & $(4.0-76.6)$ & $(0.4-26)$ & $\mathrm{p}<0.01^{*}$ \\
U/L & & & \\
Levels of Nitric Oxide & $139.4 \pm 7.4$ & $95.9 \pm 6.1$ & $\mathrm{t}=4,197$ \\
Micromol / L & $(31.5-207.5)$ & $(49.9-213.3)$ & $\mathrm{p}<0.001^{* *}$ \\
\hline
\end{tabular}

*Significant for $\mathrm{P}<0.01$

**Significant for $\mathrm{P}<0.001$

Table. 2: Breast cancer and control groups, arginase activity and nitric oxide levels and confidence intervals.

\begin{tabular}{lcl}
\hline $\begin{array}{l}\text { Parameters } \\
\text { studied }\end{array}$ & $\begin{array}{c}\text { Cancer Group } \\
(\mathbf{n = 3 0})\end{array}$ & $\begin{array}{c}\text { Healthy Group } \\
(\mathbf{n}=\mathbf{3 4})\end{array}$ \\
\hline $\begin{array}{l}\text { Arginase } \\
\text { Activity confidence }\end{array}$ & $12.6-23.1$ & $.9-8.8$ \\
interval & $(\mathrm{CI}: \% 95)$ & $(\mathrm{CI}: \% 95)$ \\
$\begin{array}{l}\text { Nitric Oxide levels, } \\
\text { confidence interval }\end{array}$ & $124.1-154.6$ & $83.4-108.3$ \\
\hline
\end{tabular}

Arginase Activities and NO Levels in Breast Cancer and Control Groups

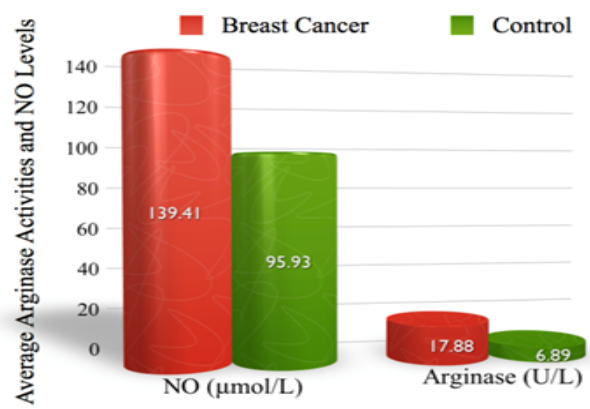

Chart. 1: Arginase activities and NO levels in breast cancer and control groups.

NO, which can easily diffuse into tissues, causes damage on cells. This molecule interacts with neuromodulators and the monoamines and stimulates their secretion into the synaptic gaps (Ohkuma and Katsura, 2001; Ceylan et al., 2011; Silberg et al., 2010). When NO, which is synthesized within the cell, diffuses out of the cell, it acts as exogenous NO and thereby stimulates the neuronal membrane depolarization (Ohkuma and Katsura, 2001). NO levels and arginase activity in our study were higher in patients with breast cancer $(\mathrm{p}<0.01)$. The increase in NO levels negatively affects oxidative phosphorylation and decreases peripheral oxygen intake in the patients (Shen et al., 1995). As a result, an energy loss occurs in brain and peripheral tissues that have not been sufficiently oxygenated. In cancer patients in whom anaerobic glycolytic pathway is preferred, as a result of all these biochemical changes, loss of energy is further increased and patients lose their life energies. Studies conducted by Savas et al. have also supported our results (Selek et al., 2008). Oxidant products and other free radicals formed by NO may have role in 
the neuropathophysiology of cancer. In addition, some reseachers have also been advocated the increase in NO levels which is protective against the cyctotoxic effect of the body. This increase can also be considered as a compensatory mechanism of the body. Because NO have been demonstrated to protect cellular and extracellular structures against $\mathrm{O}, \mathrm{O}_{2}$, and .OH radical (Wink et al., 1993). After the biochemical characteristics of arginase and NOS were clearly demonstrated, the hypothesis that arginase competes with NOS for the same substrate L-arginine and thereby inhibits the synthesis of NO were proposed. Km value of NOS is 2 to 20 $\mu \mathrm{mol} / \mathrm{L}$, while the $\mathrm{Km}$ value of arginase is 1 to $5 \mathrm{mmol} / \mathrm{L}$, but arginase activity is much higher than NOS activity at physiological concentrations of L-arginine. In this case, it has thought that both enzymes have been consumed in the same ratio ( $\mathrm{Wu}$ and Morris, 1998; Morris, 2009). As a result, although the enzyme arginase has different $\mathrm{Km}$ values, it shows much more activity while using Larginine. Genetic studies supports the idea that ariginase plays an important role in the regulation of the availability of L-arginine (Crombez and Cederbaum,2005; Iyer et al., 2002). Consequently, higher NO levels and arginase activity in patients with breast cancer than in controls may be biochemically associated with use of the same substrate by both NOS and arginase enzyme. As NOS isozymes function in different tissues, they may play a role depending on their mechanism of action of nNOS which is an isoenzyme in CNS. The localization of nNOS isoenzymes that is close to the subcellular calcium channels ensures that their activity is under strict control. The localization and physiology of this isoenzyme are among the subjects of current researches and the studies are currently underway (Schild et al., 2005). Both its physiology and the pathophysiology of the relevant diseases will be better understood with growing evidence.

Recent studies have also shown that the enzyme arginase also acts in vascular cells (Durante et al., 1997; Berkowitz et al., 2003). Although very little is known about the signaling pathways regulating the expression of arginase in these cells, cyclic adenosine monophosphate (cAMP) that is relesed in JAK(Janus Tyrosine Kinase)-STAT(Signal Transducers and Activators of Transcription) signaling pathway has been shown to induce arginase in vascular smooth muscle cells (Wei et al., 2000). Rho and Rho kinase also increase the activity of the endothelial arginase by thrombins (Ming et al., 2004; Nelin et al., 2005). Despite the detection of vascular arginase activity in vascular cells, the effect on vascular endothelium is not precisely known. Another study has shown that exogenous arginine is used by both iNOS and arginase, but it has not been revealed explicitly whether arginine synthesized in the urea cycle is utilized in the hepatic synthesis of NO (Stadler et al., 1995; Huynh and Chin-Dusting, 2006 ). Wu et al have anticipate that most of the results obtained to date may be revised and further studies will be conducted if the DNA of arginase is cloned and new information on the arginase is obtained ( $\mathrm{Wu}$ and Morris, 1998). Another study Chang and colleagues reported that arginase activity caused by the proliferation of tumor cells. According to them, the arginase and NOS can have very different influences on the growth of nearby tumor cells depending on which pathway is prevailing (Chang et al., 2001).

\section{CONCLUSIONS}

Further studies are needed to determine the relationship between NO and arginase enzyme and the exact role of this results in the etiopathogenesis of cancer. In addition, in order to fully elucidate the oxidative imbalance that is thought to be implicated in the etiopathogenesis of cancer, we believe that it will be significant and appropriate to analyze NO total oxidant, as well as antioxidant parameters and even the total oxidant status and total antioxidant status. In this study, it can be concluded that there is a significant increase in arginase activity and serum levels of NO in patients with breast cancer and these parameters can be used as a marker for cancer in the diagnosis and follow-up of treatment.

\section{COMPETING INTERESTS}

We have not provided financial support for working with any organization or institute.

\section{AUTHORS' CONTRIBUTIONS}

The third author (Celalettin Camci) wich data is interpreted and provided final revisions. The second author (Nurdan Ozlu Ceylan): data collection and participated in laboratory. I organized conceot/desing, statistical analyzes, drafting manuscript critical revision of manuscript approval of article, funding secured by.

\section{ENDNOTES}

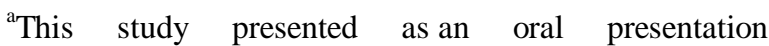
at XXIII. National Congress of Biochemistry (December 2011, Adana / TURKEY).

\section{REFERENCES}

Ahi S., Meram I., Ozdemir Y. Human serum arginase activity was measured by a sensitive enzyme properties anddevelopment of the method. Erciyes Medical Journal. 1999; 21: 3-9.

Akyol O., Zoroğlu SS., Armutcu F., Sahin S., Gurel A. Nitric Oxide as a Factor in Neuropsychiatric Disorders. In vivo. 2004; 18: 377 390 .

Berkowitz DE., White R., Li D., Minhas KM., Cernetich A., Kim S., Burke S., Shoukas AA., Nyhan D., Champion HC., Hare JM. Arginase reciprocally regulates nitric oxide syntheses activity and contributes to endothelial dysfunction in aging blood vessels. Circulation. 2003; 108: 2000-2006.

Ceylan ON., Cimenci Geyikli I., Kilıcaslan A., Bulbul F., Savas H. Alterations in Plasma Nitric Oxide Level and Arginase Activity Durind the Treatment of Bipolar Depressive Episode. Journal of Mood Disorders. 2011; 1: 1-6.

Chang CI., Liao JC., Kuo L. Macrophage Arginase Promotes Tumor Cell Growth and Suppresses Nitric Oxide-mediated Tumor Cytotoxicity. CancerResearch. 2001; 61: 1100-1106.

Cortas NK., Wakid NW. Determination of inorganic nitrate in serum and urine by a kinetic cadmium-reduction method. Clin Chem. 1990; 36: 1440-1443.

Crombez EA., Cederbaum SD. Hyperargininemia due to liver arginase deficiency. Mol Genet Metab. 2005; 84: 243-251. 
Currie GA., Gyure L., Cifuentes L. Microenvironmental arginine depletion by macrophages in vivo. Br J Cancer. 1979; 39: 613620 .

Durante W., Liao L., Peyton KJ., Schafer AI. Lysophosphatidylcholine regulates cationic amino acid transport and metabolism in vascular smooth muscle cells: Role in polyamine synthesis. J Biol Chem. 1997; 272: 154-159.

Geyer JW., Dabich D. Rapid method for determination of arginase activity in tissue homogenates. Anal Biochem. 1971; 39: 412417.

Habbema JDF., Eijkemans R., Krijnen P., Knottnerus JA.(2002). Analysis of data on the accuracy of diagnostic tests. In Knottnerus JA (Ed). The evidence base of clinical diagnosis. (pp. 117144). London: BMJ Publishing Group.

Hecker M., Nematollahi H., Hey C., Busse R., Racke K. Inhibition of arginase by $\mathrm{N}^{\mathrm{G}}$-hydroxy-L-arginine in alveolar macrophages: implications for the utilization of L-arginine for nitric oxide synthesis. FEBS Lett. 1995; 359: 251-154.

Huynh NN., Chin-Dusting J. Amino acids, arginase and nitric oxide in vascular health. Clin Exp Pharmacol Physiol. 2006; 33: 1-8.

Iyer RK., Yoo PK., Kern RM., Rozengurt N., Tsoa R., O’Brien WE., Yu H., Grody WW., Cederbaum SD. Mouse model for human arginase deficiency. Mol Cell Biol. 2002; 22: 4491-4498.

Lang TA., Secic M.(1997). Generalizing from a sample to a population: Reporting estimates and confidence intervals. In Lang TA and Secic M (Eds) How to report statistics in medicine: Annotated guidelines for authors, editors, and reviewers (pp.55-63). Philadelphia: American College of Physicians.

Levillain O., Balvay S., Peyrol S. Mitochondrial Expression of Arginase II in Male and Female Rat Inner Medullary Collecting Ducts. Journal of Histochemistry \& Cytochemistry. 2005; 53: 533-541.

Mayer B., Hemmens B. Biosynthesis and action of nitric oxide in mammalian cells. Trends Biochem Sci. 1997; 22: 477-481.

Meyer J., Richter N., Hecker M. High-Performance Liquid Chromatographic Determination of Nitric Oxide Synthase-Related Arginine Derivativesin Vitroandin Vivo. Anal. Biochem. 1997; 247: 1116.

Ming XF., Barandier C., Viswambharan H., Kwak BR., Mach F., Mazzolai L., Hayoz D., Ruffieux J., Rusconi S., Montani JP., Yang Z. Thrombin stimulates human endothelial arginase enzymatic activity via the RhoA/ROCK pathway: Implications for atherosclerotic endothelial dysfunction. Circulation. 2004; 110: 3708-3714.

Morris Jr SM. Recent advances in arginine metabolism: roles and regulation of the arginases. Br J Pharmacol 2009; 157: 922-930.

Nelin LD., Chicoine LG., Reber KM., English BK., Young TL., Liu Y. Cytokine-induced endothelial arginase expression is dependent on epidermal growth factor receptor. Am J Respir Cell Mol Biol. 2005; 33: 394-401.

Ohkuma S., Katsura M. Nitric oxide and peroxynitrite as factors to stimulate neurotransmitter release in the CNS. Prog Neurobiology. 2001; 64: 97-108.

Russell DH., McVicker TA. Polyamine biogenesis in the rat mammary gland during pregnancy and lactation. Biochem J. 1972; 130: 71-76.
Schild L., Jaroscakova I., Lendeckel U., Gerald W., Gerburg K. Neuronal nitric oxide synthesis control enzyme activity pattern of mitochondria and lipid metabolism. J FASEB. 2005; 96: 38-58.

Selek S., Savas HA., Gergerlioglu HS., Bulbul F., Uz E., Yumru $\mathrm{M}$. The course of nitric oxide and superoxide dismutase during treatment of bipolar depressive episode. J Affect Disord. 2008; 107: 89-94.

Shearer JD., Richards JR., Mills CD., Caldwell MD. Differential regulation of macrophage arginine metabolism: a proposed role in wound healing. Am J Physiol. 1997; 272: 181-190.

Shen W., Hintze TH., Wolin MS. Nitric oxide. An important signalling mechanism between vascular endothelium and parenchymal cells in the regulation of oxygen consumption. Circulation. 1995; 92: 3505-3512.

Silberg G., Ben-Shachar D., Navon R. Genetic analysis of nitric oxide synthase variants in schizophrenia and bipolar disorder. Am J Med Genet B Neuropsychiatr Genet. 2010; 5: 1318-1328.

Srivastava S., Ratha BK. Does fish represent an intermediate stage in the evolation of ureotelic cytosolic arginase I. Biochemical and Biophysical Research Communications. 2010; 391: 1-5.

Stadler J., Barton D., Beil-Moeller H., Diekmann S., Hierholzer C., Erhard W., Heidecke CD. Hepatocyte nitric oxide biosynthesis inhibits glucose output and competes with urea synthesis for L-arginine. Am J Physiol. 1995; 268: 183-188.

Szabo C., Salzman AL., Ischiropoulos H. Peroxynitritemediated oxidation of dihydrorhodamine 123 occurs in early stages of endotoxic and haemorrhagic shock and ischemia-reperfusion injury. FEBS Lett . 1995; 372: 229-232.

Tabor CW., Tabor H. Polyamines. Annu Rev Biochem. 1984; 53: 749-790

Vockley JG., Jenkinson CP., Shukla H., Kern RM., Grody WW., Cederbaum SD. Cloning and characterization of the human type II arginase gene. Genomics. 1996; 2: 118-123.

Vodovotz Y., Kwon NS., Pospischil M., Manning J., Paik J., Nathan C. Inactivation of nitric oxide synthase after prolonged incubation of mouse macrophages with IFN-gamma and bacterial lipopolysaccharide. J Immunol. 1994; 152: 4110-4118.

Wei LH., Jacobs AT., Morris SM., Ignarro LJ. IL-4 and IL-13 upregulate arginase I expression by cAMP and JAK/STAT6 pathways in vascular smooth muscle cells. Am J Physiol Cell Physiol. 2000; 279: 248256.

Wink DA., Hanbauer I., Krishna MC., De Graff W., Gamson J., Mitchell JB. Nitric oxide protects against cellular damage and cytotoxicity from reactive oxygen species. Proceedings of the National Academy of Sciences USA. 1993; 90: 9813-9817.

Wu G., Morris Jr SM. Arginine metabolism: Nitric oxide and beyond. Biochem J. 1998; 336: 1-17.

\section{How to cite this article:}

Iclal GEYIKLI, Nurdan OZLU CEYLAN, Celalettin CAMCI. Arginase activity and nitric oxide levels may be considered as tumor markers in breast cancer. J App Pharm Sci. 2012; 2(9): 031034 . 